\title{
Lehmien ajankäyttö ja lepokäyttäytymisen yhtäaikaisuus tavanomaisessa sekä automaattilypsyosastossa
} \author{
Hepola Helena $^{2)^{*}}$ \\ ${ }^{1)}$ MTT kotieläintuotannon tutkimus, Jokioinen, etunimi.sukunimi@mtt.fi \\ ${ }^{2)}$ Helsingin yliopisto, kotieläintieteen laitos, etunimi.sukunimi@helsinki.fi \\ ${ }^{3)}$ MTT palveluyksikkö, Jokioinen, etunimi.sukunimi@mtt.fi \\ * Helsingin yliopiston eläinten hyvinvoinnin tutkimuskeskuksen jäsen
}

Raussi Satu ${ }^{1)^{*}}$, Saastamoinen Seija ${ }^{2)}$, Kaihilahti Jutta ${ }^{1)^{*}}$, Eriksson Christian ${ }^{3)}$, Jauhiainen Lauri ${ }^{3)}$,

\section{Tiivistelmä}

Automaattiset lypsyjärjestelmät ovat lisänneet suosiotaan Suomen maitotiloilla. Automaattilypsynavetassa lehmän toivotaan toimivan lypsyn, ruokailun ja levon suhteen itsenäisesti. Optimaalisessa tilanteessa lehmät käyvät robottilypsyllä ympäri vuorokauden ilman ruuhkia. Nautojen käyttäytymiselle on tyypillistä, että eläimet lepäävät ja ruokailevat yhtäaikaisesti. Automaattilypsyjärjestelmissä yhtäaikaisen käyttäytymisen ylläpito voi olla vaikeaa, mikä voi osaltaan muuttaa lehmien ajankäyttöä. Tässä työssä verrattiin lehmien käyttäytymistä ja levon yhtäaikaisuutta saman navetan tavanomaisen ja automaattisen lypsyn osastoissa.

Työ tehtiin Helsingin yliopiston Suitian opetus ja koetilalla 28.10. - 18.11.2002 välisenä aikana. Navetassa oli kaksi osastoa, joista toisessa oli automaattinen lypsyjärjestelmä ja toisessa lehmät lypsettiin tavanomaisesti kaksi kertaa päivässä kalanruotoasemalla. Molemmista osastoista tarkkailtiin 17 lehmää. Tarkkailu tehtiin kuuden tunnin jaksoissa: kello 00 - 06, 06 - 12, 12 - 18 sekä 18 - 00. Kaikkia ajanjaksoja tarkkailtiin kolme kertaa peräkkäisinä viikkoina. Käyttäytyminen koodattiin viiden minuutin välein (seisoo, makaa, syö karkearehua, on väkirehukioskissa, juo, odottaa pääsyä lypsylle tai on lypsyllä). Lisäksi 5 min välein laskettiin kaikki makuulla olevat lehmät niitä yksilöimättä. Kaikki havaitut kahden lehmän väliset agonistiset yhteenotot (spontaani väistäminen, pakeneminen, uhkaaminen, puskeminen ja taisteleminen) ja nuolemiskäyttäytyminen kirjattiin. Käyttäytymisfrekvenssiaineisto analysoitiin SAS tilasto-ohjelman sekamallilla ja tulokset esitetään prosentteina havainnoista. Yhtäaikaista lepokäyttäytymistä kuvattiin ylihajontaparametrein, jotka laskettiin SAS tilasto-ohjelman logistic -proseduurin avulla.

Automaattilypsyosaston lehmät seisoivat kaikkiaan enemmän (26 vs. $15 \%$ ) ja makasivat vähemmän kello 06 - 12 (53 vs. $61 \%$ ) ja kello 18 - 00 (40 vs. $61 \%$ ) kuin tavanomaisen osaston lehmät $(\mathrm{P} \leq 0,01)$. Ne söivät kaikkiaan useammin väkirehua $(4,9$ vs. 4,0\%), mutta harvemmin karkearehua kello 06 - 12 (17 vs. $21 \%)(\mathrm{P} \leq 0,05)$. Lepokäyttäytymisen yhtäaikaisuudessa ei ollut eroa osastojen välillä, myös automaattilypsyosaston lehmät lepäsivät yhtäaikaisesti. Nuolemiskäyttäytyminen näytti olevan yleisempää automaattilypsyosastossa tavanomaiseen osastoon verrattuna (177 vs. 62 havaintoa).

Lehmien käyttäytymisen erot osastojen välillä eivät johdu pelkästään lypsyjärjestelmän erilaisuudesta, vaan myös osastojen rakenteellisista eroista: makuuparsien pituudesta, kulkukäytävien leveydestä sekä syöntipaikkojen määrästä ja sijainnista. Lehmät näyttävät pitävän kiinni lepokäyttäytymisen yhtäaikaisuudesta lypsyjärjestelmästä huolimatta. Lehmien hyvinvoinnille onkin tärkeää, että kaikissa pihattonavetoissa on jokaiselle lehmälle vähintään yksi makuuparsi.

Asiasanat: ajankäyttö, automaattinen lypsyjärjestelmä, käyttäytyminen, lehmä, tavanomainen lypsyjärjestelmä, yhtäaikainen makuukäyttäytyminen 


\section{Johdanto}

Automaattiset lypsyjärjestelmät ovat lisänneet suosiotaan Suomen maitotiloilla. Automaattilypsy mahdollistaa lehmälle joustavat lypsyajat ja useamman kuin kahdesti vuorokaudessa lypsyn. Automaattilypsy voikin parantaa lehmien maitotuotosta ja alentaa korkeatuottoisen lehmän utareeseen kohdistuvaa painetta (Wagner-Storch ja Palmer, 2003; Speroni ym., 2006). Automaattilypsylaitteen eli lypsyrobotin toiminnasta aiheutuu kuitenkin navettaan liikettä ja ääntä, lähes ympäri vuorokauden. Tämä voi häiritä lehmien lepoa ja sitä kautta vaikuttaa lehmien ajankäyttöön.

Naudat ovat sosiaalisia eläimiä ja niiden käyttäytymiseen kuuluu toimintojen yhtäaikaisuus levon ja ruokailun suhteen (Bouissou ym., 2001). Naudat käyttäytyvät yhtäaikaisemmin ollessaan laitumella kuin navetassa (O'Connell ym., 1989; Miller ja Wood-Gush, 1991). Navetassa kaikkia toimintoja ei välttämättä ole mahdollista toteuttaa yhtä aikaa, sillä tilaa ei aina ole riittävästi, jotta eläimet voisivat kunnioittaa toistensa yksilöllisiä alueita. Laitumella sen sijaan riittää tilaa toisten väistämiselle ja yhtäaikaiselle käyttäytymiselle (Miller ja Wood-Gush, 1991). Navetan hoitorutiineilla voidaan lisätä eläinten yhtäaikaista käyttäytymistä. Yhtäaikaisesti ruokailevien lehmien määrä on suurimmillaan heti uuden rehun tarjoamisen jälkeen (Miller ja Wood-Gush, 1991) ja ruuasta kilpaileminen kovimmillaan ensimmäisen puolen tunnin aikana uuden rehun tarjoamisesta (Friend ja Polan, 1974). Normaalisti lehmät lypsetään suunnilleen yhtä aikaa, mikä voi osaltaan yhtäaikaistaa eläinten käyttäytymistä. Onkin huomattu, että automaattilypsynavetoissa on yhtäaikaisesti ruokailevia lehmiä vähemmän kuin tavanomaisissa navetoissa, joskin automaattilypsylehmät tuntuvat käyvän ruokailemassa tasaisemmin (Wagner-Storch ja Palmer, 2003). Yhtäaikaisen käyttäytymisen oletettu väheneminen onkin ollut syynä ajatukseen, että automaattilypsynavetassa tultaisiin toimeen vähemmillä ruokintapaikoilla kuin tavanomaisen lypsyn navetassa. Automaattilypsyn toiminnan ajatus on, että lehmät käyvät lypsyllä, syömässä ja lepäämässä omaan yksilölliseen tahtiinsa. Tällöin vältytään ruuhkan aiheuttamilta aggressioilta sekä joutilaalta seisoskelulta. Lypsyrobotin toiminta on tällaisessa tilanteessa tasaista ja taloudellista ympäri vuorokauden. Ketelaar-de Lauwere ym. (1999) totesivat kuitenkin, että myös automaattilypsylehmät makaavat yhtäaikaisesti päästyään laitumelle, vaikka ne navetassa toimisivat lypsyn ja ruokailun suhteen yksilöllisesti.

Eläinten sosiaalinen kanssakäyminen voidaan karkeasti jakaa agonistisiin (sisältäen aggressiiviset yhteenotot niihin vastaamisen sekä spontaanin väistämisen) sekä ei-agonistisiin yhteenottoihin. Eiagonistinen kanssakäyminen sisältää toisten eläinten nuolemisen ja seksuaalisen käyttäytymisen (Bouissou ym., 2001). Vallitseva eläin voi puskea alempaansa, mikäli alempi on liian hidas väistämään, ei huomaa uhkausta tai joutuu väkisin ylittämään vallitsevan eläimen henkilökohtaisen tilan, kuten esimerkiksi navetassa tilanpuutteen vuoksi. Hyvin toimivassa arvojärjestyksessä ja väljissä olosuhteissa alempi eläin pystyy väistämään spontaanisti (Bouissou ym., 2001). Eläinten välinen nuoleminen on merkki sosiaalisten siteiden muodostumisesta ja ylläpidosta (Sato ym., 1993). Nuoleminen voi vähentää eläinten välisiä jännitteitä ja vahvistaa sosiaalisia siteitä. Nuolemisen suuri määrä onkin merkki vahvoista sosiaalisista siteistä eläinten välillä (Sato ym., 1993). Tällaiset sosiaaliset suhteet vähentävät eläinten kokemaa stressiä ja rauhoittavat eläimiä (Boissy ja Le Neindre, 1990).

Uuden tuotantoteknologian vaikutus eläinten hyvinvoinnille tulisi aina arvioida, ennen kuin teknologia otetaan yleiseen käyttöön. Eläinten käyttäytymisen tutkimus tuo tietoa navetan toimivuudesta, jolla on puolestaan suuri merkitys eläinten hyvinvoinnille. Erityisesti lehmän seisomis- ja makuukäyttäytyminen kertoo navetan toimivuudesta (Rushen, 2001). Chaplinin ym. (2000) mukaan, sorkkavaivat liittyvät vähentyneeseen ja keskeytyneeseen makuuaikaan ja lisääntyneeseen seisoskeluun parsissa. Lypsylehmät makaavat keskimäärin $13 \mathrm{~h}$ vuorokaudessa pihattonavetassa ja esimerkiksi makuuparsien vähyys (vähemmän kuin 1 makuuparsi eläintä kohti) vähentää lehmien makuuaikaa (Wierenga ja Hopster, 1990). Jos lehmillä jää liian vähän aikaa välttämättömiin toimiin, ne ovat valmiita puolustamaan makuuaikaansa syömisen ja sosiaalisten kontaktien kustannuksella (Munksgaard ym., 2005b). Munksgaardin ym. (2005a), mukaan maitorotuisen hiehon päivittäisen makuuajan tarve on noin 12 $14 \mathrm{~h}$ ja sen rajoittaminen alle $10 \mathrm{~h}$ voi vaarantaa hiehon hyvinvoinnin. Nämä tulokset osoittavat, että makuuparsi on pihattolehmälle erittäin tärkeä resurssi.

Vertasimme lehmien ajankäyttöä ja levon yhtäaikaisuutta sekä lehmien sosiaalista käyttäytymistä saman navetan sisällä olevissa automaattisen ja tavanomaisen lypsyn osastoissa. Oletuksemme oli, että automaattinen lypsyjärjestelmä muuttaa lehmien yhtäaikaista lepokäyttäytymistä, jolloin lehmien ajankäyttökin voi muuttua. 


\section{Aineisto ja menetelmät}

Koe tehtiin Helsingin yliopiston Suitian opetus- ja tutkimustilalla Holstein rotuisilla lypsylehmillä. Helsingin yliopiston eläinkoelautakunta myönsi kokeelle eläinkoeluvan. Kokeessa seurattiin 17 lehmää navetan automaattisessa lypsyosastossa ja 17 lehmää navetan tavanomaisessa lypsyosastossa. Tavanomaisen osaston lehmät lypsettiin kaksi kertaa päivässä, kello 05.00 - 06.00 ja $14.30-15.30,2$ x 5 kalanruotolypsyasemalla. Kuuden tunnin kuluttua edellisestä lypsystä automaattisen lypsyosaston lehmillä oli uudestaan lypsylupa. Lehmäliikenne automaattisen lypsyn osastossa oli ohjattu. Lehmä saattoi mennä makuualueelta ruokailualueelle joko lypsyrobotin tai automaattisen tunnistinportin kautta. Kaikki navetan lehmät saivat vapaasti säilörehua sekä väkirehua väkirehuautomaateista tuotoksensa mukaan. Väkirehua tarjottiin myös lypsyllä molemmissa osastoissa. Molemmissa osastoissa oli kaksi väkirehuautomaattia, mutta toiseen tavanomaisen osaston automaattiin oli asennettu takaportti. Automaattilypsyosaston lehmistä yksi oli poikinut viisi kertaa, yksi neljä, neljä kolme, seitsemän kaksi ja neljä yhden kerran. Tavanomaisen osaston lehmistä kolme oli poikinut viisi kertaa, kolme neljä, kaksi kolme, kolme kaksi ja kuusi yhden kerran. Kaikki lehmät olivat olleet osastossaan yli neljä kuukautta ennen kokeen aloittamista. Kokeen aikana lehmät olivat sisällä navetassa, niillä ei ollut mahdollisuutta jaloitteluun ulkona. Navettaosastojen rakenteellisia ominaisuuksia esitetään taulukossa 1.

Taulukko 1. Navetan eri osastojen, tavanomaisen ja automaattilypsyn osaston, rakenteelliset ominaisuudet.

\begin{tabular}{lcc} 
& \multicolumn{2}{c}{ Navetan osastot } \\
& tavanomainen & 27 \\
Lehmiä & 30 & 27 \\
Makuuparsien määrä & 33 & 173 \\
Makuuparren pituus (cm) & 227 & 120 \\
Makuuparren leveys (cm) & 121 & 10 \\
Karkearehun syöntipaikkojen määrä & 33 & 72 \\
Karkearehun syöntipaikan leveys (cm) & 50 & 31 kuppia \\
Juomapisteiden määrä & 3 allasta \\
Väkirehuautomaattien määrä & 2,1 takaportillinen & 2, ei takaportteja \\
Käytävän leveys karkearehun syöntipaikkojen takana (cm) & 300 & 155 \\
Käytävän leveys makuuparsien takana (cm) & 208 & 155 \\
Makuuparsien pohja ja kuivitus & kumimatto kutterikuivituksella \\
Käytävien lattia & \multicolumn{2}{c}{ betoniritilä }
\end{tabular}

\section{Ajankäyttö}

Käyttäytymishavainnot tehtiin kolmen viikon aikana 28.10 - 18.11.2002. Lehmiä tarkkailtiin neljänä päivänä viikossa. Tarkkailu tehtiin kuuden tunnin jaksoissa kello: 00 - 06, 06 - 12, 12 - 18 sekä 18 00. Jokaista ajanjaksoa tarkkailtiin kolme kertaa, kerran viikossa, peräkkäisinä viikkoina. Yhteensä tarkkailua tehtiin 72 tuntia, 12:ssa kuuden tunnin jaksossa. Lehmien käyttäytyminen koodattiin viiden minuutin välein seuraavasti: seisoo (lehmä seisoo/kävelee/juoksee, sisältäen sosiaaliset kontaktit seisten), makaa (lehmä on makuulla makuuparressa), syö karkearehua (lehmä seisoo pää ruokintapöydän yläpuolella ja sen leuat liikkuvat), on väkirehukioskissa, juo (lehmä seisoo turpa vesialtaassa tai kupissa tai sen yläpuolella) sekä odottaa pääsyä tai on lypsyllä (automaattilypsyssä: lehmä seisoo lypsyrobottiin johtavan portin takana tai portin takana seisovan toisen lehmän takana tai on lypsyrobotissa; tavanomaisessa lypsyssä: lehmä seisoo kalanruotolypsyaseman kokooma-alueella tai lypsyasemassa). Tarkkailuun osallistui samanaikaisesti kaksi tarkkailijaa, joista toinen tarkkaili automaattilypsyosaston ja toinen tavanomaisen osaston lehmiä. Tarkkailuajanjaksot ja osastot tasapainotettiin tarkkailijoiden kesken. Lehmien kylkiin maalattiin tunnistamisen helpottamiseksi numerot ihmisten hiusten vaalennukseen tarkoitetulla aineella.

\section{Yhtäaikainen lepokäyttäytyminen ja sosiaalinen käyttäytyminen}

Viiden minuutin välein laskettiin myös kaikki parressa makuulla olevat lehmät molemmissa osastoissa lehmiä yksilöimättä. Kaikki havaitut kahden lehmän väliset agonistiset yhteenotot ja nuolemistapah- 
tumat sekä näiden tapahtumapaikka (väkirehukioski, ruokintapöytä, käytävä, makuuparsi tai lypsyn kokooma-alue) kirjattiin. Agonistisiksi yhteenotoiksi laskettiin spontaani väistäminen, pakeneminen, uhkaaminen, puskeminen ja taisteleminen. Keskinäiseen nuolemiseen laskettiin kuuluvaksi kaikki toisen lehmän nuoleminen lukuun ottamatta genitaalialueen nuolemista (Bouissou ym., 2001).

\section{Tilastolliset analyysit}

Havainnot kirjattiin paperilomakkeelle ja siirrettiin myöhemmin tietokoneen taulukkolaskentaohjelmaan ja siitä edelleen SAS 9.1 tilasto-ohjelmaan. Käyttäytymisfrekvenssiaineisto analysoitiin SAS tilasto-ohjelman sekamalli -proseduurilla. Mallissa $y_{\mathrm{ijk}}=\mu+\mathrm{D}_{\mathrm{i}}+\mathrm{T}_{\mathrm{j}}+\mathrm{DT}_{\mathrm{ij}}+\varepsilon_{\mathrm{ijk}}, \mu$ on yleiskeskiarvo ja $D_{i}, T_{j}$ sekä $D_{i j}$ ovat kiinteitä tekijöitä, osasto (tavanomainen tai automaattilypsy), ajanjakso (00 06, $06-12,12-18,18$ - 24) tai osasto-ajanjakso yhdysvaikutus tekijöitä. Ajanjaksotekijää ei otettu huomioon lypsylle odottamis- ja lypsyllä olo-havainnoissa, tavanomaisen osaston kiinteistä ja automaattilypsyosaston satunnaisista lypsyajoista johtuen. Tulokset esitetään prosentteina havainnoista.

Yhtäaikaista lepokäyttäytymistä, oikeammin sen vastakohtaa, yksilöllistä lepokäyttäytymistä, kuvattiin ylihajontaparametrein, jotka laskettiin SAS logistic -proseduurin avulla. Mallinnus tehtiin binomijakaumaoletuksella ( $1=$ lehmä lepää, $0=$ lehmä ei lepää). Binomijakaumassa oletetaan, että lehmien makuuhavainnot ovat toisistaan riippumattomia eli että lehmät tekevät yksilöllisesti, ilman toisten lehmien vaikutusta, päätöksen makaamisestaan. Mikäli ylihajonta on yli yhden, on varianssi suurempi kuin binomijakaumassa oletetaan. Tällaisessa tapauksessa oletus lehmien yksilöllisestä päätöksestä lepokäyttäytymisen suhteen hylätään ja todennäköisimpänä syynä ilmiöön pidetään lehmien yhtäaikaista käyttäytymistä. Ylihajontaparametrit laskettiin viikoittain ja ajanjaksoittain molemmille osastoille erikseen. Lisäksi laskettiin ylihajontaparametrien suhteellinen erotus, joka puolestaan testattiin SAS tilasto-ohjelman sekamallilla. Sosiaalisen käyttäytymisen tulokset esitetään havaintojen määränä sekä osuuksina havainnoista osastoittain ja tapahtumapaikoittain eriteltynä.

\section{Tulokset ja tulosten tarkastelu \\ Ajankäyttö}

Seisominen ja makaaminen

Automaattilypsyosaston lehmät seisoivat kaiken kaikkiaan tavanomaisen osaston lehmiä useammin ( $26 \%$ vs. $15 \%, \mathrm{P}<0.001)$. Tavanomaisen osaston lehmät lepäsivät automaattilypsyosaston lehmiä useammin ajanjaksolla $06-12$ (61\% vs. $53 \%$, P<0.01) sekä ajanjaksolla $18-00$ (61\% vs. $40 \%$, $\mathrm{P}<0,001)$.

Ketelaar-de Lauwere ym. (1996) havaitsivat, että automaattinen lypsyjärjestelmä voi lisätä aikaa, jonka lehmät käyttävät odottamiseen. Yksi syy automaattilypsyosaston lehmien pitempään seisomisaikaan tässä kokeessa voi olla automaattilypsyosaston kapeammat käytävät (tavanomainen osasto $208-300 \mathrm{~cm}$ vs. automaattilypsyosasto $155 \mathrm{~cm}$ ). Lehmän liikkumisen vapaus navetassa on riippuvainen osaston muista lehmistä (Miller ja Wood-Gush, 1991). Hierarkiasta johtuen alemman lehmän on vaikeaa ylittää ylemmän lehmän henkilökohtainen alue. Alemman lehmän onkin odotettava, kunnes ylempi lehmä siirtyy pois tieltä, ennen kuin se pääsee esimerkiksi karkearehupöytään tai makuuparteen. Automaattilypsyosaston karkearehunsyöntipaikkojen vähäisempi määrä (10 automaattilypsyosastossa vs. 33 tavanomaisessa osastossa) saattoi myös osaltaan olla syynä lehmien lisääntyneeseen seisoskeluun. Suosituimpaan ruokailuaikaan osa automaattilypsyosaston lehmistä joutui odottamaan päästäkseen säilörehupöytään.

Lehmien makuuaikaan vaikuttavat navetan ympäristö ja hoitorutiinit. Tilanahtaus esimerkiksi vähentää lehmien makuuaikaa (Wierenga ja Hopster, 1990). Tavanomaisen osaston lehmillä oli tässä kokeessa hieman enemmän mahdollisuuksia valita makuupaikkansa, sillä tavanomaisessa osastossa makuuparsia oli kolme enemmän kuin lehmiä, kun taas automaattilypsyosastossa makuuparsia oli yksi lehmää kohti. Makuuparren pehmeys ei ollut kokeessamme erottava tekijä, sillä kaikki parret oli päällystetty ja kuivitettu molemmissa osastoissa samalla tavalla.

Lehmien ja hiehojen tulisi saada levätä yli 10 tuntia päivässä (Jensen ym., 2005; Munksgaard ym., 2005a). Vähentynyt makuuaika lisää lehmien jalkasairauksien todennäköisyyttä (Chaplin ym., 2000) ja altistaa lehmät stressille (Fisher ym., 2002). Automaattilypsyosaston lehmät makasivat tässä kokeessa $48 \%$ havainnoista, mikä on tunneiksi muutettuna keskimäärin $11 \mathrm{~h}$ vuorokaudessa. Tavanomaisen osaston lehmillä vastaavat luvut olivat $53 \%$ ja $13 \mathrm{~h}$. Lehmät saivat mahdollisesti riittävästi 
lepoa molemmissa osastoissa, mutta 2 h ero keskimääräisessä makuuajassa on huomattava ja haastaa pohtimaan eron syitä.

Makuuparret erosivat kokeemme osastoissa pituudeltaan, mutta parsien leveys oli eri osastoissa sama. Tavanomaisen osaston parret olivat $0,5 \mathrm{~m}$ pidemmät kuin automaattilypsyosaston. Ero saattoi vaikuttaa automaattilypsylehmien vähäisempään makuuaikaan ja lisääntyneeseen seisomisaikaan, sillä makuuparren mittojen tiedetään vaikuttavan lehmien makuuaikaan (Haley ym., 2000; Tucker ym., 2004; Veissier ym., 2004). Leveämmissä parsissa lehmät makasivat Tuckerin ym. (2004) kokeessa tunnin pidempään kuin kapeammissa parsissa. Leveämmissä parsissa lehmät seisoskelivat kapeampia parsia enemmän siten, että kaikki neljä jalkaa olivat parressa (Tucker ym., 2004). Lehmä voi altistua sorkkasairauksille seisoessa etujalat parressa ja takajalat käytävällä (Galindo ja Broom, 2000; Veissier ym., 2004).

Automaattilypsylehmien sykevälivaihtelun perusteella laskettu levon aikainen stressitaso saattaa Hagenin ym. (2005) mukaan olla suurentunut ja stressinsietokyky alentunut verrattuna tavanomaisesti lypsettyihin lehmiin. Lypsyrobotista lähtee lähes $24 \mathrm{~h}$ vuorokaudessa ääntä, joka voi tutkimusnavettamme kaltaisessa pienessä navettatilassa häiritä lepääviä lehmiä ja ajaa ne ylös rasittaen lehmiä vähentäen niiden lepoa.

Automaattilypsyosaston lehmien vähäisempi lepo tavanomaisen osaston lehmiin verrattuna johtui todennäköisesti osastojen olosuhde-eroista, kuten automaattilypsyosaston lyhyemmistä makuuparsista, kapeammista käytävistä, lypsyrobotin aiheuttamasta häiriöstä tai vähäisemmästä säilörehunsyöntipaikkojen määrästä. Pelkän automaattilypsyn osuutta osastojen välisiin lepo ja seisomiskäyttäytymisen eroihin on mahdotonta tästä aineistosta erottaa.

\section{Säilörehun ja väkirehun syöminen sekä juominen}

Tavanomaisen osaston lehmät söivät säilörehua useammin kuin automaattilypsyosaston lehmät ajanjaksolla $06-12(21 \%$ vs. $17 \%, \mathrm{P}<0,05)$. Väkirehukioskeissa vierailu oli kaiken kaikkiaan yleisempää automaattilypsyosastossa verrattuna tavanomaiseen osastoon $(4,9 \%$ vs. 4,0 \%, P<0.05). Vedenjuonnissa ei havaittu eroja osastojen tai ajanjaksojen välillä.

Säilörehua oli lehmille tarjolla vapaasti ja säilörehu jaettiin automaattisilla vaunuilla. Uutta rehua jaettiin molemmille osastoille kaksi kertaa päivässä. Rehunjakoajat sattuivat tarkkailujakson 06 12 alkuun sekä 12 - 18 loppuun. Nämä ajankohdat olivat myös vilkkainta säilörehunsyöntiaikaa. Uuden rehun jakaminen aktivoi lehmiä syömään (Miller ja Wood-Gush, 1991; DeVries ym., 2004). Automaattilypsyosaston lehmät eivät pystyneet kaikki syömään yhtäaikaisesti toisin kuin tavanomaisen osaston lehmät. Tämä voi selittää sen, miksi tavanomaisen osaston lehmät söivät automaattilypsyosaston lehmiä tiheämmin säilörehua ajanjaksolla $06-12$.

Automaattilypsyosaston lehmäliikenteen järjestelyt voivat myös vaikuttaa lehmien ruokailukäyttäytymiseen. Vapaassa lehmäliikenteessä, missä lehmät saavat kulkea navetassa täysin vapaasti makuuosaston, ruokintaosaston ja lypsyrobotin välillä, on havaittu kuiva-aineen syönnin lisääntyneen ja märehtimisajan pidentyneen verrattuna ohjatumpaan lehmäliikenteeseen (Melin ym., 2007). Kokeessamme ei täten ollut lehmien syömisen kannalta optimaalinen lehmäliikennejärjestely, sillä liikenne Suitian automaattilypsyosastossa oli portein ohjattu.

Säilörehunsyöntipaikkojen vähäinen määrä voi olla yksi lisääntyneen seisoskelun syy kokeemme automaattilypsyosastossa, sillä lehmät joutuivat seisten odottamaan vuoroaan päästäkseen säilörehupöytään. Tämä odottelu ja seisoskelu saattoi olla pois lehmien lepoajasta. Säilörehun syöntipaikkojen vähentäminen automaattilypsynavetassa saattaakin olla kyseenalaista, jos se altistaa lehmät joutilaalle seisoskelulle.

Väkirehuautomaatteja oli molemmissa osastoissa kaksi. Automaattilypsyosaston väkirehuautomaatit sijaitsivat kapean käytävän toisella puolella, vastapäätä karkearehunsyöntialuetta. Lehmät saattoivatkin helposti käydä väkirehuautomaatilla odottaessaan pääsyä karkearehupöytään. Runsas lehmämäärä ahtaassa ruokintatilassa voi lisätä häirintää eli puskemista sekä tönimistä väkirehuautomaatilla, jolloin lehmän väkirehuautomaattikäynti voi keskeytyä (Katainen ym., 2005). Keskeytynyt ruokailukäynti voi johtaa useampiin käynteihin automaatilla, sillä osa väkirehuannoksesta voi yhä olla saamatta. Tavanomaisen osaston väkirehuautomaatit sijaitsivat rauhallisella makuuparsikäytävällä. Väkirehukioskien sijainti on voinut johtaa siihen, että tavanomaisen osaston lehmillä oli vähemmän mahdollisesti keskeytymättömiä automaattikäyntejä. Tavanomaisen osaston toisessa väkirehuautomaatissa ollut takaportti on myös osaltaan voinut rauhoittaa ruokailutilannetta vähentämällä häirintää. 
Lehmien juontikäyttäytymisessä ei havaittu eroja osastojen välillä. Ilmeisesti lehmät saivat riittävästi juodakseen molemmissa osastoissa, vaikka osastojen vesilähteet olivat hyvin erilaiset. Automaattilypsyosastossa oli 31 vesikuppia, joista 27 oli makuuparsien etuosassa parsien välissä ja neljä säilörehunsyöntiparsien välissä. Tavanomaisessa osastossa oli kolme vesiallasta. Iso vesiallas on lehmille mieluisa juontipaikka ja Cook and Nordlund (2004) suosittelevat lehmäryhmää kohti vähintään kahta vesiallasta.

\section{Lypsyn odottaminen ja lypsy}

Lypsyn odottaminen ja lypsy vei enemmän aikaa tavanomaisesti lypsetyiltä lehmiltä verrattuna automaattilypsyosaston lehmiin $(6,2 \%$ vs. $2,6 \%, \mathrm{P}<0,001)$.

Hagenin ym. (2004) mukaan tavanomainen lypsy vie keskimäärin enemmän aikaa (15 min) kuin automaattilypsy ( 9 min), mutta lypsylle odottamisaikaa ei heidän kokeessaan mitattu. Kokeessamme automaattilypsyosastossa oli vain 27 lehmää, vaikka yksi lypsyrobotti pystyy lypsämään noin 60 lehmää. Tämän vuoksi automaattilypsyosaston lehmät tuskin joutuivat usein odottamaan lypsylle pääsyä. Toisaalta määritelmämme lypsyvuoroa odottavasta lehmästä ei välttämättä kattanut kaikkia lehmiä, jotka halusivat päästä lypsylle. Tavanomaisen osaston kaikki 33 lehmää koottiin ennen lypsyä lypsyaseman odotusalueelle, missä ne eivät juuri voineet tehdä muuta kuin seisoa ja odottaa lypsyvuoroa. Tämä odottaminen vei paljon aikaa, erityisesti lypsyvuoroltaan viimeisiltä lehmiltä.

\section{Yhtäaikainen lepokäyttäytyminen ja sosiaalinen käyttäytyminen}

Yhtäaikaisen lepokäyttäytymisen ylihajonta ei eronnut osastojen tai ajanjaksojen välillä. Automaattilypsyosastossa lepokäyttäytymisen ylihajonta tarkkailuajanjaksojen yli tarkasteltuna oli 1,8 ja tavanomaisessa osastossa 1,6. Osastojen välinen ylihajontojen suhteellinen ero oli $28 \%(\mathrm{P}=0,15)$. Lehmät siis lepäsivät yhtäaikaisesti molemmissa osastoissa. Molemmissa osastoissa myös oli vähintään yksi makuuparsi lehmää kohti, joten niillä oli mahdollisuus yhtäaikaiseen lepoon. Makuuparsien vähyyden tiedetään vähentävän makuuaikaa (Wierenga ja Hopster, 1990) ja altistavan lehmät stressille (Friend ym., 1979). Toisin kuin oletimme, automaattinen lypsyjärjestelmä ei muuttanut lehmien yhtäaikaista lepokäyttäytymistä, vaikkakin automaattilypsyosaston lehmät lepäsivät muuten tavanomaisen osaston lehmiä vähemmän.

Molemmissa osastoissa havaittiin lähes yhtä paljon agonisitisia yhteenottoja (automaattilypsyosasto 180 havaintoa vs. tavanomainen osasto 171 havaintoa). Suurin osa agonistisista yhteenotoista automaattilypsyosastossa tapahtui kahden väkirehuautomaatin läheisyydessä (44\% tapahtumista). Muita agonististen yhteenottojen tapahtumapaikkoja automaattilypsyosastossa olivat käytävät, säilörehupöytä ja makuuparsi ( $25 \%, 18 \%$ ja $13 \%$ tapahtumista). Tavanomaisessa osastossa agonistiset yhteenotot tapahtuivat käytävillä, karkearehupöydässä, väkirehuautomaattien läheisyydessä, parsissa ja lypsyn kokooma-alueella (36\%, 25\%, $19 \%, 13 \%$ ja $7 \%$ tapahtumista). Automaattilypsyosastossa näytti olevan enemmän kahdenvälistä nuolemista verrattuna tavanomaiseen osastoon (177 vs. 62 havaintoa). Automaattilypsyosastossa suurin osa kahdenvälisistä nuolemisista havaittiin karkearehupöydässä (79 \% tapahtumista), muut paikat olivat käytävä ja makuuparsi (14 \% ja $7 \%$ tapahtumista). Tavanomaisessa osastossa vuorostaan nuolemiskäyttäytyminen oli lähes yhtä yleistä käytävällä (47\% tapahtumista) kuin karkearehupöydässä (43\% tapahtumista) ja vähemmän sitä havaittiin makuuparsissa (10\% tapahtumista).

Toisten eläinten nuolemisen on todettu vähentävän paitsi eläinten välisiä jännitteitä myös stressaavien olosuhteiden vaikutusta (Boissy ja Le Neindre, 1990; Sato ym., 1993). Automaattilypsyosastomme oli ahtaampi kuin tavanomaisen lypsyn osasto, joka tarjosi lehmille enemmän mahdollisuuksia väistää ylempiään. Automaattilypsyosaston lehmät joutuivat ylittämään toistensa henkilökohtaisen tilan melko usein päästäkseen erityisesti karkearehupöytään. Tiheä toisten eläinten nuoleminen saattoi vähentää automaattilypsyosastossa lehmien välisiä jännitteitä ja pitää aggressiivisen käyttäytymisen tason melko alhaisena ahtaista tiloista huolimatta.

\section{Johtopäätökset}

Tavanomaisen osaston lehmät lepäsivät enemmän ja seisoivat vähemmän kuin automaattilypsyosaston lehmät, mutta tavanomaisella osastolla lehmiltä kului enemmän aikaa lypsyn odotukseen ja lypsyyn. Pelkän lypsyjärjestelmän osuutta osastojen välisiin käyttäytymiseroihin on tämän kokeen perusteella mahdotonta selvittää, sillä osaston rakenteellisilla eroilla oli varmasti osuutta lehmien käyttäytymi- 
seen. Automaattilypsyosaston kapeammat kulkukäytävät, lyhyemmät makuuparret, väkirehuautomaattien sijainti ja vähäisemmät karkearehunsyöntipaikat vaikuttivat osastojen väliseen lehmien käyttäytymisen eroihin. Lehmien lepokäyttäytyminen oli yhtenäistä sekä automaatti- että tavanomaisessa lypsyosastossa. Automaattilypsy ei näytä vaikuttavan lehmien yhtäaikaiseen lepokäyttäytymiseen. Lehmien hyvinvoinnille onkin edullista, että kaikissa pihattonavetoissa on vähintään yksi makuuparsi lehmää kohti.

\section{Kirjallisuus}

Boissy, A. \& Le Neindre, P. 1990. Social Influences on the Reactivity of Heifers: Implications for Learning Abilities in Operant Conditioning. Appl. Anim. Behav. Sci. 25: 149-165.

Bouissou, M.F., Boissy, A., Le Neindre, P. \& Veissier, I. 2001. The Social Behaviour of Cattle. Teoksessa: Keeling, L.J. \& Gonyou, H.W. (toim.), Social Behaviour in Farm Animals. CAB International. Wallingford, pp. 113-145.

Chaplin, S.J., Ternent, H.E., Offer, J.E., Logue, D.N. \& Knight, C.H. 2000. A Comparison of Hoof Lesions and Behaviour in Pregnant and Early Lactation Heifers at Housing. Vet. J. 159: 147-153.

Cook, N.B. \& Nordlund, K.V. 2004. Behavioural needs of the transition cow and considerations for special needs facility design. Vet. Clin. North Am. Food Anim. Pract. 20: 495-520.

DeVries, T.J., von Keyserlingk, M.A.G. \& Weary, D.M. 2004. Effect of Feeding Space on the Inter-Cow Distance, Aggression, and Feeding Behavior of Free-Stall Housed Lactating Dairy Cows. J. Dairy Sci. 87: 14321438.

Fisher, A.D., Verkerk, G.A., Morrow, C.J. \& Matthews, L.R. 2002. The effects of feed restriction and lying deprivation on pituitary-adrenal axis regulation in lactating cows. Livest. Prod. Sci. 73: 255-263.

Friend, T.H. \& Polan, C.E. 1974. Social Rank, Feeding Behavior, and Free Stall Utilisation by Dairy Cattle. J. Dairy Sci. 57: 1214-1220.

Friend, T.H., Gwazdauskas, F.C. \& Polan, C.E. 1979. Change in Adrenal Response from Free Stall Competition. J Dairy Sci. 62: 768-771.

Galindo, F. \& Broom, D.M. 2000. The relationships between social behaviour of dairy cows and the occurrence of lameness in three herds. Res. Vet. Sci. 69: 75-79.

Hagen, K., Langbein, J., Schmied, C., Lexer, D. \& Waiblinger, S. 2005. Heart rate variability in dairy cowsinfluences of breed and milking system. Physiol. Behav. 85: 195-204.

Hagen, K., Lexer, D., Palme, R., Troxler, J. \& Waiblinger, S. 2004. Milking of Brown Swiss and Austrian Simmental cows in a herringbone parlour or an automatic milking unit. Appl. Anim. Behav. Sci. 88: 209-225.

Haley, D.B., Rushen, J. \& de Passillé, A.M. 2000. Behavioural indicators of cow comfort: activity and resting behaviour of dairy cows in two types of housing. Can. J. Anim. Sci. 80: 257-263.

Jensen, M.B., Pedersen, L.J. \& Munksgaard, L. 2005. The effect of reward duration on demand functions for rest in dairy heifers and lying requirements as measured by demand functions. Appl. Anim. Behav. Sci. 90: 207217

Katainen, A., Norring, M., Manninen, E., Laine, J., Orava, T., Kuoppala, K. \& Saloniemi, H. 2005. Competitive behaviour of dairy cows at a concentrate self-feeder. Acta Agric. Scand., Sect. A, Anim. Sci. 55: 98-105. Ketelaar-de Lauwere, C.C., Devir, S. \& Metz, J.H.M. 1996. The influence of social hierarchy on the time budget of cows and their visits to an automatic milking system. Appl. Anim. Behav. Sci. 49: 199-211.

Melin, M., Pettersson, G., Svennersten-Sjaunja, K. \& Wiktorsson, H. 2007. The effects of restricted feed access and social rank on feeding behaviour, ruminating and intake for cows managed in automated milking systems. Appl. Anim. Behav. Sci. 107: 13-21.

Miller, K. \& Wood-Gush, D.G.M. 1991. Some effects of housing on the social behaviour of dairy cows. Anim. Prod. 53: 271-278.

Munksgaard, L., Jensen, M.B., Herskin, M.S. \& Lovendahl, P. 2005a. The need for lying time in high producing dairy cows. In: Kusunose, R., Sato, S. (Eds.), Proceedings of the $39^{\text {th }}$ International Congress of the ISAE, p. 38 .

Munksgaard, L., Jensen, M.B., Pedersen, L.J., Hansen, S.W. \& Matthews, L. 2005b. Quantifying behavioural priorities - effects of time constraints on behaviour of dairy cows, Bos taurus. Appl. Anim. Behav. Sci. 92: 3-14.

O’Connell, J., Giller, P.S. \& Meaney, W. 1989. A Comparison of Dairy Cattle Behavioural Patterns at Pasture and During Confinement. Ir. J. Agric. Res. 28: 65-72.

Rushen, J. 2001. Assessing the Welfare of Dairy Cattle. J. Appl. Anim. Welf. Sci., 4: 223-234.

Sato, S., Tarumizu, K. \& Hatae, K. 1993. The influence of social factors on allogrooming in cows. Appl. Anim. Behav. Sci. 38: 235-244.

Speroni, M., Pirlo, G. \& Lolli, S. 2006. Effect of Automatic Milking Systems on Milk Yield in a Hot Environment. J. Dairy Sci. 89: 4687-4693. 
Tucker, C.B., Weary, D.M. \& Fraser, D. 2004. Free-Stall Dimensions: Effects on Preference and Stall Usage. J. Dairy Sci. 87: 1208-1216.

Veissier, I., Capdeville, J. \& Delval, E. 2004. Cubicle housing systems for cattle: Comfort of dairy cows depends on cubicle adjustment. J. Anim. Sci. 82: 3321-3337.

Wagner-Storch, A.M. \& Palmer, R.W. 2003. Feeding Behavior, Milking Behavior, and Milk Yields of Cows Milked in a Parlor Versus an Automatic Milking System. J. Dairy Sci. 86: 1494-1502.

Wierenga, H.K., Hopster, H. 1990. The Significance of Cubicles for the Behaviour of Dairy Cows. Appl. Anim. Behav. Sci. 26: 309-337. 